\title{
The relationship between prosocial and antisocial behaviors in sport, general self-efficacy and academic self-efficacy: Study in department of physical education and sport teacher education
}

\author{
Mevlüt Yildız ${ }^{1}$ \\ Ender Şenel ${ }^{3}$ \\ Hasan Şahan ${ }^{4}$
}

\begin{abstract}
The aim of this study was to examine the relationship between prosocial and antisocial behaviors in sport, general self-efficacy and academic self-efficacy beliefs of students studying in physical education and sport teacher education department. 118 students in department of physical education and sport teacher education at Mugla Sitki Kocman University voluntarily participated in the study. 31 of the participants were national athletes while 87 of them were non-national athletes. 50 of the participant were females while 68 of them were males. Prosocial and Antisocial Behavior in Sport Scale (PABSS) was used to determine the behaviors of students whether prosocial or antisocial. General self-efficacy scale was used to determine the self-efficacy beliefs of participants. Academic Self-Efficacy scale was used to determine academic self-efficacy beliefs of students. Positive correlations have been found between age and prosocial opponent. Positive correlations have been found between general self-efficacy and prosocial teammate, prosocial opponent. Positive correlations have been found between academic self-efficacy and prosocial teammate, prosocial opponent, general-self-efficacy. Consequently, students having high level of self-efficacy beliefs in physical education and sport teacher education department can adopt prosocial behaviors.
\end{abstract}

Keywords: Prosocial; Antisocial; General self-efficacy; Academic self-efficacy; Physical education.

\section{Introduction}

Social cognitive theory focuses on a self-system allows individuals to control over their opinions, feelings and actions (Schunk \& Pajares, 2010). In social cognitive theory, people function as individuals contributing their own motivation, behaviors and development in a network of

\footnotetext{
1 Research assistant, Mugla Sitki Kocman University, Faculty of Sport Sciences, Coaching Education, mevlutyildizz@gmail.com

${ }^{3}$ Research assistant, Mugla Sitki Kocman University, Faculty of Sport Sciences, Physical Education and Sport Teacher, endersenel@gmail.com

4 Associate Prof. Dr., Akdeniz University, School of Physical Education and Sport, Sport Management, hasanshn@gmail.com
} 
Yıldız, M., Șenel, E., \& Șahan, H. (2015). The relationship between prosocial and antisocial behaviors in sport, general self-efficacy and academic self-efficacy: Study in department of physical education and sport teacher education. International Journal of Human Sciences, 12(2), 1273-1278. doi:10.14687/ijhs.v12i2.3202

interaction (Bandura, 1989). Self-efficacy is a concept that Bandura proposed in social cognitive theory. According to Schunk and Pajares (2010), self-efficacy beliefs are the self-perceptions related to their own capabilities. Bong and Skaalvik (2003) have suggested that self-efficacy predicts cognitive and self-regulatory processes.

Because self-efficacy is about social factor, it can also be said that it is related to individuals' behaviors. Prosocial and antisocial behaviors in sport have been used to define preventive and proactive (effective in future) aspects of morality (Kavussanu, 2006; Sage, Kavussanu, \& Duda, 2006). Prosocial behaviors have been defined as actions or behaviors for helping people or being beneficial for another person such as an opponent or a team mate while anti social behaviors are total opposite. Antisocial behaviors are intentions to harm or disadvantage another person (Eisenberg \& Fabes, 1998; Sage et al., 2006; Kavussanu, Seal, \& Phillips, 2006; Weinstein \& Ryan, 2010). Sage (2006) has suggested that helping an opponent, congratulating an opponent can be examples of prosocial behavior in sport. Behaviors such as cheating, aggression, physical and verbal abuses have been given as antisocial behaviors in sport (Sage, 2006). Hodge and Londsdale (2011) have stated, "Verbally encouraging a teammate and physically intimidating an opponent are prosocial and antisocial behaviors in sport, respectively." Briefly, it can be said that prosocial behaviors are closely related to fair play concept and antisocial behaviors are against the nature of this concept, because fair play is defined as social, cultural and moral norms of sport without being limited with awareness of rules (Yildiran and Sezen, 2006).

Students in physical education and sport teacher education department will be the most important part of the moral values in sport and society because of the structure of the physical education lessons. Physical education and sport teachers should also have higher self-efficacy beliefs than other branches because they teach activities requiring self-beliefs. For these reasons, it is important to examine the relationships between these two social concepts. The aim of this study was to examine the relationship between prosocial and antisocial behaviors in sport, general self-efficacy and academic self-efficacy beliefs of students studying in physical education and sport teacher education department.

\section{Material and Method}

118 students in department of physical education and sport teacher education at Mugla Sitki Kocman University voluntarily participated in the study. 31 of the participants were national 
Yıldız, M., Șenel, E., \& Șahan, H. (2015). The relationship between prosocial and antisocial behaviors in sport, general self-efficacy and academic self-efficacy: Study in department of physical education and sport teacher education. International Journal of Human Sciences, 12(2), 1273-1278. doi:10.14687/ijhs.v12i2.3202

athletes while 87 of them were non-national athletes. 50 of the participant were females while 68 of them were males.

Prosocial and Antisocial Behavior in Sport Scale (PABSS) was used to determine the behaviors of students whether prosocial or antisocial. The scale was developed by Kavussanu and Boardley (2009) and adapted to Turkish language by Sezen-Balcikanli (2013). Cronbach's alpha value has been found to be 0.81 for prosocial and antisocial behavior in sport scale. The scale has four subdimensions including prosocial teammate, prosocial opponent, antisocial teammate and antisocial opponent.

General self-efficacy scale developed by Schwarzer and Jerusalem (1995) and adapted to Turkish by Yesilay et al. (1996) was used to determine the self-efficacy beliefs of participants. In samples from 23 nations, Cronbach's alphas ranged from .76 to .90 , with the majority in the high .80 s.Cronbach's alpha value has been found to be 0.84 for general self-efficacy scale (http://userpage.fuberlin.de/health/engscal.htm). Academic Self-Efficacy scale, developed by Jerusalem and Schwarzer (1981), adapted to Turkish by Yllmaz, Gürçay and Ekinci (2007) was used to determine academic self-efficacy beliefs of students. Cronbach's alpha value has been found to be 0.69 for academic self-efficacy scale.

\section{Results}

Table 1. Differences between prosocial and antisocial behaviors, self-efficacy and academic self-efficacy in terms of gender

\begin{tabular}{lcccccccc}
\hline \multicolumn{1}{c}{ Variables } & \multicolumn{7}{c}{ Female } & \multicolumn{7}{c}{ Male } \\
\hline & $\mathrm{n}$ & $\mathrm{X}$ & $\mathrm{S} . \mathrm{S}$. & $\mathrm{n}$ & $\mathrm{X}$ & $\mathrm{S} . \mathrm{S}$. & $\mathrm{t}$ & $\mathrm{p}$ \\
Prosocial Team Mate & 50 & 3.59 & .98 & 68 & 4.04 & .75 & -2.84 & 0.05 \\
Prosocial opponent & 50 & 3.09 & .90 & 68 & 3.75 & .88 & -3.98 & $\mathbf{0 . 0 0}^{* *}$ \\
Antisocial Team Mate & 50 & 2.48 & .87 & 68 & 2.55 & .85 & -.47 & 0.63 \\
Antisocial opponent & 50 & 2.44 & .73 & 68 & 2.65 & .79 & -1.49 & 0.13 \\
General Self-Efficacy & 50 & 3.04 & .49 & 68 & 3.07 & .45 & -.34 & 0.73 \\
Academic Self-Efficacy & 50 & 2.92 & .53 & 68 & 3.06 & .45 & -1.46 & 0.14 \\
\hline
\end{tabular}

${ }^{* *} \mathrm{p}<0.01$

Differences between prosocial and antisocial behaviors, self-efficacy and academic self-efficacy in terms of gender were shown in table 1. Significant difference was found between male and female in terms of prosocial opponent dimension $(\mathrm{p}<0.05)$. Male students reported higher scores than females in this dimension. No significant differences were found between genders in terms of prosocial teammate, antisocial teammate, antisocial opponent, and self-efficacy and academic selfefficacy $(\mathrm{p}>0.05)$. 
Yıldız, M., Șenel, E., \& Șahan, H. (2015). The relationship between prosocial and antisocial behaviors in sport, general self-efficacy and academic self-efficacy: Study in department of physical education and sport teacher education. International Journal of Human Sciences, 12(2), 1273-1278. doi:10.14687/ijhs.v12i2.3202

Table 2. Differences between being national or non-national athlete in terms of prosocial and antisocial behaviors, general self-efficacy and academic self-efficacy

\begin{tabular}{lcccccccc}
\hline \multicolumn{1}{c}{ Variables } & National Athlete & \multicolumn{7}{c}{ None National } \\
\hline & $\mathrm{n}$ & $\mathrm{X}$ & $\mathrm{S} . S$. & $\mathrm{n}$ & $\mathrm{X}$ & $\mathrm{S} . S$. & $\mathrm{t}$ & $\mathrm{p}$ \\
Prosocial Team Mate & 31 & 3.91 & .94 & 87 & 3.82 & .86 & .495 & .622 \\
Prosocial opponent & 31 & 3.56 & .94 & 87 & 3.44 & .95 & .651 & .516 \\
Antisocial Team Mate & 31 & 2.54 & .92 & 87 & 2.51 & .84 & .136 & .892 \\
Antisocial opponent & 31 & 2.59 & .93 & 87 & 2.55 & .71 & .233 & .816 \\
General Self-Efficacy & 31 & 3.12 & .44 & 87 & 3.03 & .48 & .865 & .389 \\
Academic Self-Efficacy & 31 & 3.10 & .51 & 87 & 2.97 & .48 & 1.251 & .214 \\
\hline
\end{tabular}

Differences between being national or non-national athlete in terms of prosocial and antisocial behaviors, general self-efficacy and academic self-efficacy were displayed in table 2. Although national athletes reported higher scores than none-athletes, these results were found to be statistically insignificant.

Table 3. Correlations between sub-dimensions of prosocial and antisocial behaviors, general self-efficacy and academic self-efficacy

\begin{tabular}{|c|c|c|c|c|c|c|c|}
\hline & $\begin{array}{l}\underset{b}{\vec{b}} \\
\underset{d g}{d}\end{array}$ & 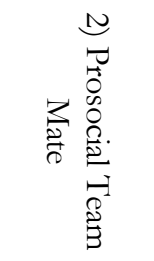 & 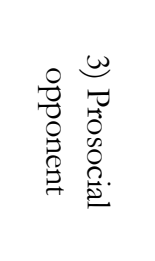 & 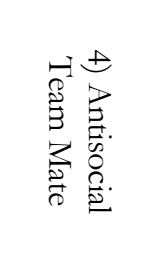 & 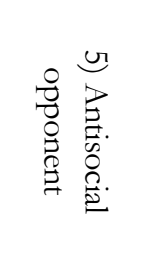 & 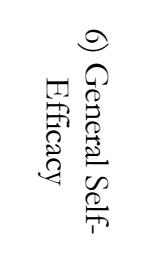 & 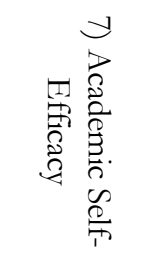 \\
\hline & $21.98 \pm 2.07$ & $3.85 \pm 0.88$ & $3.47 \pm 0.94$ & $2.52 \pm 0.86$ & $2.56 \pm 0.77$ & $3.05 \pm 0.47$ & $3.00 \pm 0.49$ \\
\hline 1 & 1 & & & & & & \\
\hline 2 & .086 & 1 & & & & & \\
\hline 3 & $.191^{*}$ & $.437^{* *}$ & 1 & & & & \\
\hline 4 & -.063 & .021 & -.030 & 1 & & & \\
\hline 5 & -.053 & $.164^{*}$ & .049 & $.693^{* *}$ & 1 & & \\
\hline 6 & -.060 & $.325^{* *}$ & $.176^{*}$ & .047 & .069 & 1 & \\
\hline 7 & -.059 & $.234^{* *}$ & $.316^{* *}$ & .031 & .044 & $.440^{* *}$ & 1 \\
\hline
\end{tabular}

Correlations between sub-dimensions of prosocial and antisocial behaviors, self-efficacy and academic self-efficacy were displayed in table 3. Positive correlations have been found between age and prosocial opponent $(\mathrm{r}=.191, \mathrm{p}<0.05)$. Positive correlations have been found between general self-efficacy and prosocial teammate $(r=.325, \mathrm{p}<0.01)$, prosocial opponent $(\mathrm{r}=.176, \mathrm{p}<0.05)$. Positive correlations have been found between academic self-efficacy and prosocial teammate $(r=.234, p<0.01)$, prosocial opponent $(r=.316, p<0.05)$, general-self-efficacy $(r=.440, p<0.01)$.

\section{Discussion and Conclusion}

The aim of this study was to examine the relationship between prosocial and antisocial behaviors in sport, general self-efficacy and academic self-efficacy beliefs of students studying in physical 
Yıldız, M., Șenel, E., \& Șahan, H. (2015). The relationship between prosocial and antisocial behaviors in sport, general self-efficacy and academic self-efficacy: Study in department of physical education and sport teacher education. International Journal of Human Sciences, 12(2), 1273-1278. doi:10.14687/ijhs.v12i2.3202

education and sport teacher education department.

Difference between genders in terms of prosocial and antisocial behaviors in sport, general and academic self-efficacy beliefs have been examined. It has been found that male students reported higher scores than females in prosocial opponent dimension while no significant differences have been found in terms of other dimension. Besides, differences between being a national athlete and non-national athlete have been examined. Although national athletes reported higher scores than none-athletes, these results have been found to be statistically insignificant.

Positive correlations have been found between age and prosocial opponent $(r=.191, p<0.05)$. Positive correlations have been found between general self-efficacy and prosocial teammate $(\mathrm{r}=.325, \mathrm{p}<0.01)$, prosocial opponent $(\mathrm{r}=.176, \mathrm{p}<0.05)$. Positive correlations have been found between academic self-efficacy and prosocial teammate $(r=.234, p<0.01)$, prosocial opponent $(\mathrm{r}=.316, \mathrm{p}<0.05)$, general-self-efficacy $(\mathrm{r}=.440, \mathrm{p}<0.01)$. Bandura, Camprara, Barbanelli, Pastorelli \& Regalia (2001) have found positive correlations between prosocial behavior and academic selfefficacy ( $r=.41, \mathrm{p}<0.001)$, social self-efficacy $(\mathrm{r}=.43, \mathrm{p}<0.001)$. Camprara, Barbanelli, Pastorelli, Bandura, \& Zimbardo (2000) have found that early prosocial behavior strongly predicts subsequent level of academic achievement. d'Arripe-Longueville et al. (2010) have found positive correlations between prosocial behavior and negative affective self-regulatory efficacy $(r=.27, p<0.01)$, resistive self-regulatory efficacy $(r=.21, p<0.01)$, social efficacy $(r=.26, p<0.01)$. Şenel (2013) has found positive correlation between general self-efficacy and academic self-efficacy $(r=0,580, p<0.05)$.

Consequently, it can be referred that students having high level of self-efficacy beliefs in physical education and sport teacher education department can adopt prosocial behaviors. Physical education and sport schools are the places where moral values and good behaviors in sport are taught pedagogically. Physical education and sport teacher education departments are very important to prevent violence in sport and encourage fair play behaviors. Although education of moral values in schools and training in sport clubs are different from each other, they should work together.

\section{References}

Bandura, A. (1989). Social cognitive theory. In R. Vasta (Ed.), Annals of child development. Vol.6. Six theories of child development (pp. 1-60). Greenwich, CT: JAI Press.

Bandura, A. (1990). Reflections on nonability determinants of competence. In R. J. Sternberg \& J. Kolligian, Jr. (Eds.), Competence Considered (315 - 262). New Haven, CT: Yale University Press. 
Yıldız, M., Șenel, E., \& Șahan, H. (2015). The relationship between prosocial and antisocial behaviors in sport, general self-efficacy and academic self-efficacy: Study in department of physical education and sport teacher education. International Journal of Human Sciences, 12(2), 1273-1278. doi:10.14687/ijhs.v12i2.3202

Bandura, A., Caprara, G. V., Barbaranelli, C., Pastorelli, C., Regalia, C. (2001). Sociocognitive SelfRegulatory Mechanisms Governing Transgressive Behavior. Journal of Personality and Social Psychology, 80(1), 125 - 135.

Bong, M., Skaalvik, E. M. (2003). Academic self-concept and self-efficacy: How different are they really? Educational Psychology Review, 15(1), 1-40.

Caprara, G. V., Barbaranelli, C., Pastorelli, C., Bandura, A., \& Zimbardo, P. G. (2000). Prosocial foundations of children's academic achievement. American Psychological Society, 11(4), 302 306.

d'Arripe-Longueville, F., Corrion, K., Scoffier, S., Roussel, P., \& Chalabaev, A. (2010). Sociocognitive self-regulatory mechanisms governing judgments of the acceptability and likelihood of sport cheating. Journal of Sport \& Exercise Psychology, 32, 595-618.

Eisenberg, N., \& Fabes, R.A. (1998). Prosocial development. In N. Eisenberg (Ed.), Hand- book of child psychology. Vol 3: Social, emotional, and personality development (pp. 701-778). New York: John Wiley.

Hodge, K. \& Lonsdale, C. (2011). Prosocial and Antisocial Behavior in Sport: The Role of Coaching Style, Autonomous vs. Controlled Motivation, and Moral Disengagement. Journal of Sport \& Exercise Psychology, 33, 527-547

Jerusalem, M. and Schwarzer, R. (1981). Fragebogen zur Erfassung von "Selbstwirksamkeit. Skalen zur Befindlichkeit und Persoenlichkeit In R. Schwarzer (Hrsg.). (Forschungsbericht No. 5). Berlin: Freie Universitaet, Institut fuer Psychologie.

Kavussanu, M. (2006). Motivational predictors of prosocial and antisocial behavior in football. Journal of Sports Sciences, 24, 575-588.

Kavussanu, M., \& Boardley, I. (2009). The Prosocial and Antisocial Behavior in Sport Scale. Journal of Sport \& Exercise Psychology, 31, 97-117.

Kavussanu, M., Seal, A., \& Phillips, D. (2006). Observed prosocial and antisocial behaviors in male soccer teams: Age differences across adolescence and the role of motivational variables. Journal of Applied Sport Psychology, 18, 326-344.

Sage, L., Kavussanu, M., \& Duda, J.L. (2006). Goal orientations and moral identity as predictors of prosocial and antisocial functioning in male association football players. Journal of Sports Sciences, 24, 455-466.

Sage, L. D. (2006). Predictors Of Moral Behaviour In Football, Unpublished Doctoral Dissertation, School of Sport and Exercise Sciences University of Birmingham

Schunk, D. H., Pajares, F. (2010). Self-efficacy beliefs. In Sana Järvelä (Ed.) Social and Emotional Aspects of Learning (2011, 668-672). Oxford: Elsevier: Academic Press.

Şenel, E. (2013). Evaluation of Some Factors Affecting Self-efficacy Beliefs of Students in Physical Education and Sport Teaching Department and Students in the Some Other Fields of Teacher Education Departments. Unpublished Master Thesis, Gazi University Institute of Educational Sciences, Ankara.

Weinstein, N., \& Ryan, R.M. (2010). When helping helps: Autonomous motivation for prosocial behavior and its influence on well-being for the helper and the recipient. Journal of Personality and Social Psychology, 98, 222-244.

Yılmaz, M., Gürçay, D., Ekici, G. (2007). Akademik öz yeterlik ölçeğinin Türkçeye uyarlanması. Hacettepe Üniversitesi Eğitim Fakültesi Dergisi (H. U. Journal of Education), 33, 253 - 259.

- http://userpage.fu-berlin.de/ health/turk.htm (Retrieved on 15.12.2014).

-http://userpage.fu-berlin.de/health/engscal.htm (Retrieved on 15.12.2014). 